\title{
Fibroblast growth factor 19 expression correlates with tumor progression and poorer prognosis of hepatocellular carcinoma
}

Seiki Miura, Noboru Mitsuhashi, Hiroaki Shimizu, Fumio Kimura, Hiroyuki Yoshidome, Masayuki Otsuka, Atsushi Kato, Takashi Shida, Daiki Okamura and Masaru Miyazaki

\begin{abstract}
Background: Although fibroblast growth factor 19 (FGF19) can promote liver carcinogenesis in mice, its involvement in human hepatocellular carcinoma (HCC) has not been well investigated. FGF19, a member of the FGF family, has unique specificity for its receptor FGFR4. This study aimed to clarify the involvement of FGF19 in the development of HCC.

Methods: We investigated human FGF19 and FGFR4 expression in 40 hepatocellular carcinoma specimens using quantitative real-time reverse transcription polymerase chain reaction (RT-PCR) analysis and immunohistochemistry. Moreover, we examined the expression and the distribution of FGF19 and FGFR4 in 5 hepatocellular carcinoma cell lines (HepG2, HuH7, HLE, HLF, and JHH7) using RT-PCR and immunohistochemistry. To test the role of the FGF19/ FGFR4 system in tumor progression, we used recombinant FGF19 protein and small interfering RNA (siRNA) of FGF19 and FGFR4 to regulate their concentrations.

Results: We found that FGF19 was significantly overexpressed in HCCS as compared with corresponding noncancerous liver tissue $(P<0.05)$. Univariate and multivariate analyses revealed that the tumor FGF19 mRNA expression was an independent prognostic factor for overall and disease-free survival. Moreover, we found that the FGF19 recombinant protein could increase the proliferation $(P<0.01, n=12)$ and invasion $(P<0.01, n=6)$ capabilities of human hepatocellular carcinoma cell lines and inhibited their apoptosis $(P<0.01, n=12)$. Inversely, decreasing FGF19 and FGFR4 expression by siRNA significantly inhibited proliferation and increased apoptosis in $\mathrm{JHH7}$ cells $(P<0.01, n=12)$. The postoperative serum FGF19 levels in HCC patients was significantly lower than the preoperative levels $(P<0.01, n=29)$.
\end{abstract}

Conclusions: FGF19 is critically involved in the development of HCCs. Targeting FGF19 inhibition is an attractive potential therapeutic strategy for HCC.

\section{Background}

Hepatocellular carcinoma (HCC) is a highly aggressive solid tumor associated with poor prognosis [1]. Curative therapies of surgical treatment, including hepatic resection and liver transplantation, improve the chances of survival of patients with HCC [2-4]. However, a limited number of patients can be treated with surgery because of the damage to liver function. The prognosis for most patients remains poor after surgery for multicentric

\footnotetext{
* Correspondence: noborumitsuhashi@gmail.com

Department of General Surgery, Graduate School of Medicine, Chiba University, 1-8-1, Inohana, Chuo-ku, Chiba 260-0856, Japan
}

recurrence and intrahepatic metastasis [5,6]. Therefore, the development of a systemic therapy that targets a new molecule involved in HCC is needed.

Fibroblast growth factor (FGF) signaling plays an important role in a variety of processes, including proliferation, cellular differentiation, wound repair, and angiogenesis [7-9]. It has been reported that amplification or overexpression of FGFs is associated with the pathogenesis of malignant neoplasms, such as leukemias and sarcomas as well as stomach, pancreas, bladder, colon, breast, and prostate cancer [10-15]. Further, several correlations between overexpression, polymorphism, 
translocation, and truncation of FGF receptor (FGFR) and a variety of human neoplasms such as myeloma, breast, stomach, colon, bladder, and cervical cancer have also been reported [16-21]. Therefore, the FGF/FGFR system plays a critical role in tumor progression.

FGF19 was first identified on the basis of its amino acid similarities to murine FGF15 (53\% identity) [22]. FGF19 is currently unique in displaying apparent specificity for FGFR4 $[23,24]$. Previous studies have reported that FGF19 and hepatocyte FGFR4 regulate biosynthesis in the bile duct by repression of CYP7A1 [25]. Further, FGF19 reportedly increases the metabolic rate, reduces body weight, and reverses diabetes in both high-fat-fed mice and leptin-deficient mice [26]. On the other hand, ectopic expression of FGF19 in mice promotes hepatocyte proliferation, hepatocellular dysplasia, and neoplasia [27]. Moreover, recent reports have revealed that a neutralizing antibody that selectively blocks the interaction of FGF19 with FGFR4 inhibits the growth of colon tumors and the formation of liver tumors in vivo [28]. However, although the involvement of FGF19 in HCC has been demonstrated, no study has so far addressed the significance of FGF19 expression or clarified its role in the mechanism of HCC development in humans [29].

In this study, we hypothesized that the FGF19/FGFR4 system is activated in patients with HCC and is correlated with the aggressiveness of the tumor. We elucidated the association between the FGF19/FGFR4 system and the development of HCC using human samples and in vitro experimental models.

\section{Methods}

\section{Patients and specimens}

Cancerous tissues and surrounding non-cancerous hepatic parenchyma were obtained from 40 primary HCC Japanese patients who underwent curative resection surgery at Chiba University Hospital, Japan, from January 1995 to December 2001. They did not have any other malignancies. The ethics committee of Chiba University Hospital approved this study. Informed consent was obtained from every patient for the use of resected tissue before the study began. Samples were obtained from 31 men and 9 women aged 49-78 years. Specimens were histologically classified by the Japanese staging system of the Liver Cancer Study Group of Japan [30]. In the corresponding noncancerous parenchyma, cirrhosis was found in 14 patients (35\%).

\section{Cells}

The human HCC cell lines HuH7, HepG2, HLE, HLF, PLC/PRF/5, JHH1, JHH2, JHH5, JHH6, and JHH7 were obtained from the Health Science Research Resources Bank (Osaka, Japan). HuH7, HepG2, HLE, HLF, and PLC/PRF/5 were cultured in Dulbecco's Modified
Eagle's Medium containing 10\% fetal bovine serum (Sigma-Aldrich Corp., St. Louis, MO). JHH1, JHH2, JHH5, JHH6, and JHH7 were cultured in William's Medium E with $10 \%$ fetal bovine serum. Primary cultures of human hepatocytes were prepared and cultured as described in previous papers [31].

\section{RNA extraction and cDNA synthesis}

Total RNA from the cell lines and tissues was isolated using RNeasy Mini Kits (Qiagen, Hilden, Germany) according to the manufacturer's protocol. Specimens were taken from viable and non-fibrotic areas of tumors and noncancerous tissues. They were quickly frozen in liquid nitrogen and then stored at $-80^{\circ} \mathrm{C}$ until use. Synthesis of cDNA from total RNA was conducted using a Ready-to-Go ${ }^{\circledR}$ cDNA synthesis kit (Amersham Biosciences Corp., Piscataway, NJ) following the manufacturer's protocols.

\section{Real-time quantitative RT-PCR analysis}

The expressions of FGF19 and FGFR4 were examined by reverse transcription polymerase chain reaction (RTPCR) with the following primers: (forward) (5'-TCT CCT CTG ACT TCA ACA GCG ACA C-3') and (reverse) (5'-TGT TGC TGT AGC CAA ATT CGT TGT C-3') for human GAPDH, (forward) (5'-CAG CTG TAC AAG AAC AGA GGC TTT C-3') and (reverse) (5'-AAA TGG GTC CAT GCT GTC GGT CTC C-3') for FGF19, and (forward) (5'-CAT CCG CTG GCT TAA GGA TGG AC-3') and (reverse) (5'-ATC ACG AGA CTC CAG TGC TGA TG-3') for FGFR4. All PCR reactions were performed using the SYBR Green PCR Core Reagents kit (Perkin-Elmer Applied Biosystems, Foster City, CA, USA) under the following conditions: 1 cycle at $95^{\circ} \mathrm{C}$ for $10 \mathrm{~min}, 50$ cycles at $95^{\circ} \mathrm{C}$ for $10 \mathrm{sec}$, $60^{\circ} \mathrm{C}$ for $5 \mathrm{sec}, 72^{\circ} \mathrm{C}$ for $10 \mathrm{sec}$, and $80^{\circ} \mathrm{C}$ for $1 \mathrm{sec}$. Realtime detection of the SYBR Green emission intensity was conducted with a LightCycler ${ }^{\circledR}$ (Roche, Mannheim, Germany). An equivalent amount of cDNA sample, derived from $40 \mathrm{ng}$ total RNA, was used for each PCR reaction. The mRNA in each sample was then automatically quantified with reference to the standard curve constructed with each use of the LightCycler ${ }^{\circledR}$. Quantitative RT-PCR was performed at least three times per sample. To standardize the amount of RNA, we quantified the expression of GAPDH mRNA in each sample and then divided the amounts of expressed FGF19 and FGFR4 mRNA by that of GAPDH.

\section{Immunohistochemical staining}

An immunohistochemical analysis was performed on paraffin-embedded sections using the Envision kit (Dako, Glostrup, Denmark) following the manufacturer's instructions. The sections were boiled in retrieval 
solution to expose antigens. Anti-FGF19 (R\&D Systems, Inc., MN) monoclonal antibodies, anti-FGFR4 (Santa Cruz Biotechnology, Inc., Santa Cruz, CA) monoclonal antibodies and control antibody (R\&D Systems, Inc., $\mathrm{MN}$ ) were applied as the primary antibodies to the sections at a dilution of $25 \mu \mathrm{g} / \mathrm{mL}$ and 1:50. The section slides were counterstained with hematoxylin, dehydrated, and mounted. The immunostaining was evaluated independently by two pathologists.

\section{Cell fixation and staining}

HuH7, HepG2, HLE, HLF, and JHH7 cells $\left(1 \times 10^{4} /\right.$ well $)$ were seeded and cultured at $37^{\circ} \mathrm{C}$ in a humidified $5 \% \mathrm{CO}_{2}$ atmosphere for $24 \mathrm{~h}$. Then, the cells were washed 3 times with phosphate-buffered saline (PBS) and fixed in 100\% acetone for $10 \mathrm{~min}$ at $4^{\circ} \mathrm{C}$. After fixation, cells were washed 3 times with PBS. Cells were blocked in blocking serum at room temperature for $1 \mathrm{~h}$ in a humidified chamber. Cells were washed 3 times with PBS and stained at the same dilution as paraffin-embedded sections.

\section{Cell proliferation assay with FGF19 recombinant protein} Cells were seeded $\left(6 \times 10^{3} /\right.$ well $)$ with FGF19 recombinant protein (Cell Sciences, MA, USA) at concentrations of $0.1,1,10$, or $100 \mathrm{ng} / \mathrm{mL}$ and cultured. After 48, 72, or 96 h, $20 \mu \mathrm{L}$ of Cell Titer $96^{\circledR} \mathrm{AQ}_{\text {ueous }}$ (Promega, WI, USA) was added to the culture media then incubated for $1 \mathrm{~h}$ at $37^{\circ} \mathrm{C}$ in a humidified $5 \% \mathrm{CO}_{2}$ atmosphere. Then, the absorbance of each of the plates at $490 \mathrm{~nm}$ was recorded using a 96-well plate reader (Bio-Rad, CA, USA). The proliferation index (PI) was defined as OD values of the recombinant protein-treated cells divided by those of the untreated control cells. We examined proliferation assay with 12 chambers in the same condition at the same time.

\section{Cell apoptosis assay with FGF19 recombinant protein}

Cells were harvested at $48 \mathrm{~h}$ after seeding and incubation with $1 \mathrm{ng} / \mathrm{ml}$ of FGF19 recombinant protein. To initiate apoptosis, 5-fluorouracil (5-FU) (Roche) was added at a final concentration of $10 \mu \mathrm{g} / \mathrm{mL}$. After further incubation and gravity sedimentation for $24 \mathrm{~h}$, the supernatant was removed carefully and the cell pellets were resuspended in $200 \mu \mathrm{L}$ lysis buffer. Then, ELISA was performed using the Cell Death Detection Kit (Roche) according to the manufacturer's specifications. The apoptosis index (AI) was defined as OD values of recombinant protein-treated cells divided by those of the controls. We examined apoptosis assay with 12 chambers in the same condition at the same time.

\section{Invasion assay with FGF19 recombinant protein}

Double-chamber transwell plates with $8-\mu \mathrm{m}$ pore-size polycarbonate membrane inserts at the base of the upper chamber (Cell Biolabs, Inc., San Diego, CA) were used. Here, $300 \mu \mathrm{L}$ of warm, serum-free media was added to each upper chamber and incubated for $1 \mathrm{~h}$ at $37^{\circ} \mathrm{C}$. Upper chambers containing the reconstituted Matrigel membranes were set into the lower chambers of the 24-well cluster plates. JHH7 cells were trypsinized, counted, and resuspended with fresh medium before being plated into the upper chambers of the assay wells. Approximately $1 \times 10^{6}$ cells were plated in $300 \mu \mathrm{L}$ of defined medium into each upper chamber. Then, $500 \mu \mathrm{L}$ of medium was added to each lower chamber. Both the media in the upper and lower chambers contained $1 \mathrm{ng} / \mathrm{ml}$ of human recombinant FGF19. $\mathrm{JHH} 7$ were cultured in this way for $48 \mathrm{~h}$ in a humidified $5 \% \mathrm{CO}_{2}$ atmosphere. The medium in the upper chamber was then aspirated, and cells from its inner surface were wiped off using a cotton swab. The membranes were stained with $400 \mu \mathrm{L}$ of Cell Stain Solution and incubated for $10 \mathrm{~min}$ at room temperature. Stained inserts were gently washed several times with water. Then, the stained inserts were transferred to an empty well containing $200 \mu \mathrm{L}$ of extraction solution and incubated for $10 \mathrm{~min}$ on an orbital shaker. Subsequently, $100 \mu \mathrm{L}$ from each sample was transferred to a 96-well microtiter plate, and the OD $560 \mathrm{~nm}$ of each sample was measured in a 96-well plate reader (Bio-Rad, Hercules, CA). We examined invasion assay with 6 chambers in the same condition at the same time.

\section{Migration assay with FGF19 recombinant protein}

Migration assay was performed by using transwell plates with $8 \mu \mathrm{m}$ pore (BD Biosciences). JHH7 cells $\left(1 \times 10^{5}\right)$ suspended in $500 \mu \mathrm{l}$ serum-free Williams medium were seeded into the upper part, whereas the lower compartment was filled with $1 \mathrm{ml}$ medium with $1 \mathrm{ng} / \mathrm{ml}$ of the human FGF19 recombinant protein. After incubation for $24 \mathrm{~h}$ at $37^{\circ} \mathrm{C}$ in $5 \% \mathrm{CO}_{2}$, non-migrating cells were removed from the upper surface of the membrane by scrub. Cells on the reverse side were stained with $0.1 \%$ crystal violet, and counted under a microscope at x100 magnification. We examined migration assay with 6 chambers in the same condition at the same time.

\section{Gene knockdown using small interfering RNA transfection} Transfections of FGF19, FGFR4 and non-targeting negative control small interfering RNA (siRNA) (AMBION, Austin, TX) were conducted with Lipofectamine 2000 (Invitrogen, Carlsbad, CA) in 96-well plates according to the manufacturer's specifications. The day before transfection, the JHH7 cells were trypsinized, counted, and seeded at $6 \times 10^{3}$ cells per well into 96-well plates. Lipofectamine 2000 diluted in Opti-MEM (Invitrogen) was supplemented to the siRNA mixture. The mixture was incubated for $20 \mathrm{~min}$ at room temperature. The mixture 
and Opti-MEM were added to the plate to a final siRNA concentration of $20 \mathrm{nM}$.

\section{Flow cytometry}

Control and FGFR4-specific siRNA were transfected into JHH7 as described above. At $72 \mathrm{~h}$ after transfection, the cells were collected and stained with either a phycoerythrin-conjugated anti-FGFR4 antibody (BioLegend, San Diego, CA) or an isotype-matched control (R\&D systems, Minneapolis, MN). Flow cytometric analysis of cell surface FGFR4 was performed using a FACSCalibur analyzer (Becton Dickinson Immunocytometry Systems, San Jose, CA).

\section{Cell proliferation assay after FGF19 and FGFR4 siRNA transfection}

Cells $\left(6 \times 10^{3}\right.$ per well) were seeded into 96-well plates, cultured for $24 \mathrm{~h}$, and transfected with control, FGF19, or FGFR4 siRNA. At $72 \mathrm{~h}$ after transfection, cells were harvested. Then, $20 \mu \mathrm{L}$ of Cell Titer $96^{\circledR}$ AQueous (Promega) was added to the culture media and incubated for $2 \mathrm{~h}$ at $37^{\circ} \mathrm{C}$ in a humidified $5 \% \mathrm{CO}_{2}$ atmosphere. The absorbance of the plates at $490 \mathrm{~nm}$ was recorded using a 96-well plate reader (Bio-Rad).

\section{Apoptosis assay after FGF19 and FGFR4 siRNA transfection}

Cells $\left(6 \times 10^{3}\right.$ per well) were seeded into 96-well plates, cultured for $24 \mathrm{~h}$, and transfected with control, FGF19, or FGFR4 siRNA. Cells were harvested at $72 \mathrm{~h}$ after transfection. To initiate apoptosis, 5-FU (Roche) at a final concentration of $10 \mu \mathrm{g} / \mathrm{mL}$ was added. After further incubation and gravity sedimentation for $24 \mathrm{~h}$, the supernatant was carefully removed, and the cell pellets were resuspended in $200 \mu \mathrm{L}$ lysis buffer. Then, ELISA was performed using the Cell Death Detection Kit (Cell Biolabs, Inc.) according to the manufacturer's specifications.

\section{Changes in serum FGF19 levels in patients with HCC after hepatectomy}

Blood serum was obtained from 10 healthy subject and 29 primary HCC patients who underwent curative resection at Chiba University Hospital, Japan, from 2005 to 2007 (22 men, 7 women). The samples were obtained on the day before and the day after surgery. A sandwich ELISA kit was used for colorimetric detection of FGF19 in serum (FGF19 Quantikine ELISA kit, Minneapolis, $\mathrm{MN}$ ) following the manufacturer's instructions.

\section{Statistical analysis}

The relative mRNA expression levels (FGF19/GAPDH and FGFR4/GAPDH) were calculated from the quantified data. Mann-Whitney's $U$ test was used to analyze the differences in the FGF19 and FGFR4 expression levels between HCCs and the corresponding noncancerous hepatic tissues. To analyze the correlation between FGF19, FGFR4, and clinicopathological parameters, differences in the numerical data between the two groups were evaluated using the Kruskal-Wallis test. Overall and disease-free survival rates were then calculated using the Kaplan-Meier method, and the differences in survival curves were analyzed using the log-rank test. Survival was counted if the patient was still alive or had died of other causes. Independent prognostic factors were analyzed by the Cox proportional hazards regression model in a stepwise manner. All the statistical analyses were performed using Stat View software (Version 5.0, Abacus Concepts, Berkeley, CA). Data are expressed as mean \pm SE. $P<0.05$ denoted the presence of a statistically significant difference.

\section{Results}

\section{FGF19 and FGFR4 expression in HCC}

We examined $40 \mathrm{HCC}$ samples and corresponding noncancerous hepatic tissues for FGF19 mRNA expression using real-time quantitative RT-PCR. The average FGF19/GAPDH level in HCCs was significantly higher than that in noncancerous tissues. (Figure $1 \mathrm{~A} ; P=$ 0.015), whereas FGFR4 was not significantly overexpressed in HCCs compared to noncancerous tissues (Figure $1 \mathrm{~B}, P=0.055)$. An immunohistochemical study using anti-FGF19 monoclonal antibodies was performed to determine whether FGF19 protein was expressed in HCC specimens. FGF19 protein was detectable in both cancer and noncancerous tissues Figure 1C). FGF19 staining was observed in the cytoplasm of tumor cells and noncancerous hepatocytes, and tended to be greater in the tumor cells. FGFR4 staining was not significantly greater in the membranes of tumor cells as compared to those of cells from corresponding noncancerous tissue (Figure 1D).

\section{Correlation between FGF19 mRNA expression and clinicopathological parameters in HCC}

The correlation between FGF19 expression and clinicopathological parameters in patients with HCC is shown in Table 1. Significant correlation was found only between FGF19 mRNA expression and pathological stage. (Table $1, P=0.049$ ).

\section{Univariate and multivariate analysis of prognostic factors for patients with HCC}

For statistical analysis of FGF19 levels, the specimens were divided into two groups based on the median value of tumor FGF19 mRNA $\left(5.7 \times 10^{-4}\right)$ : a high expression group $(n=20)$ and a low expression group $(\mathrm{n}=20)$. We analyzed disease-free survival rates and 


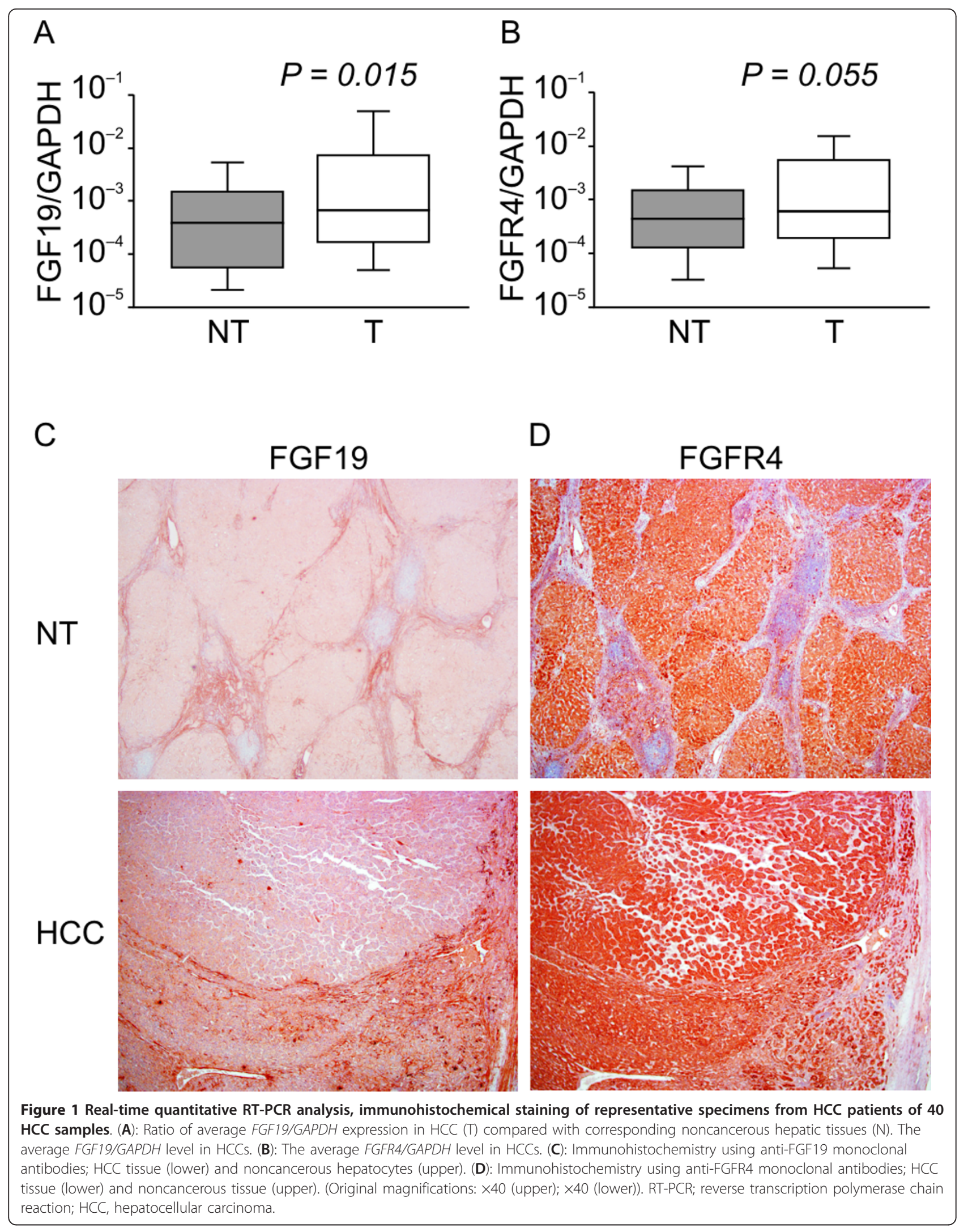


Table 1 Correlations between FGF19 expression and clinicopathological parameters in 40 patients with HCC

\begin{tabular}{|c|c|c|c|}
\hline Clinicopathological parameters & Patient number & Tumor FGF19 mRNA* (Mean \pm SE) & $P$ value \\
\hline \multicolumn{4}{|l|}{$\overline{\text { Age }}$} \\
\hline$<65$ years & 23 & $0.007 \pm 0.006$ & 0.505 \\
\hline$\geq 65$ years & 17 & $0.016 \pm 0.014$ & \\
\hline \multicolumn{4}{|l|}{ Gender } \\
\hline Male & 31 & $0.014 \pm 0.009$ & 0.319 \\
\hline Female & 9 & $0.003 \pm 0.002$ & \\
\hline \multicolumn{4}{|l|}{ Virus } \\
\hline HBV & 4 & $0.058 \pm 0.058$ & 0.808 \\
\hline $\mathrm{HCV}$ & 27 & $0.002 \pm 0.001$ & \\
\hline None & 9 & $0.017 \pm 0.016$ & \\
\hline \multicolumn{4}{|l|}{ Miran Criteria } \\
\hline $\ln$ & 17 & $0.001 \pm 0.000$ & 0.194 \\
\hline Out & 23 & $0.0019 \pm 0.011$ & \\
\hline \multicolumn{4}{|l|}{ AFP } \\
\hline$<10 \mathrm{ng} / \mathrm{mL}$ & 20 & $0.013 \pm 0.012$ & 0.194 \\
\hline$\geq 10 \mathrm{ng} / \mathrm{mL}$ & 20 & $0.009 \pm 0.007$ & \\
\hline \multicolumn{4}{|l|}{ Tumor size } \\
\hline$<5 \mathrm{~cm}$ & 20 & $0.001 \pm 0.000$ & 0.137 \\
\hline$\geq 5 \mathrm{~cm}$ & 20 & $0.021 \pm 0.013$ & \\
\hline \multicolumn{4}{|l|}{ Histologic type of tumor } \\
\hline Well differentiated & 6 & $0.001 \pm 0.001$ & 0.808 \\
\hline Moderately differentiated & 31 & $0.014 \pm 0.009$ & \\
\hline Poorly differentiated & 3 & $0.002 \pm 0.001$ & \\
\hline \multicolumn{4}{|l|}{ Formation of fibrous capsule } \\
\hline Present & 39 & $0.011 \pm 0.007$ & -—— \\
\hline Absent & 1 & 0.0002 & \\
\hline \multicolumn{4}{|l|}{ Capsular infiltration } \\
\hline Present & 38 & $0.012 \pm 0.007$ & 0.718 \\
\hline Absent & 2 & $0.0003 \pm 0.0003$ & \\
\hline \multicolumn{4}{|l|}{ Septal formation } \\
\hline Present & 30 & $0.014 \pm 0.009$ & 0.445 \\
\hline Absent & 10 & $0.002 \pm 0.002$ & \\
\hline \multicolumn{4}{|l|}{ Serosal invasion } \\
\hline Present & 1 & 0.016 & -二- \\
\hline Absent & 39 & $0.011 \pm 0.007$ & \\
\hline \multicolumn{4}{|l|}{ Portal invasion } \\
\hline Present & 30 & $0.014 \pm 0.009$ & 0.449 \\
\hline Absent & 10 & $0.002 \pm 0.002$ & \\
\hline \multicolumn{4}{|l|}{ Hepatic vein invasion } \\
\hline Present & 10 & $0.024 \pm 0.023$ & 0.269 \\
\hline Absent & 30 & $0.007 \pm 0.005$ & \\
\hline Intrahepatic metastasis & & & 0.580 \\
\hline Present & 22 & $0.008 \pm 0.006$ & \\
\hline Absent & 18 & $0.015 \pm 0.013$ & \\
\hline \multicolumn{4}{|l|}{ Bile duct invasion } \\
\hline Present & 1 & 0.232 & -—— \\
\hline Absent & 39 & $0.005 \pm 0.004$ & \\
\hline \multicolumn{4}{|l|}{ Lymph node metastasis } \\
\hline Present & 1 & 0.001 & -—- \\
\hline Absent & 39 & $0.011 \pm 0.007$ & \\
\hline
\end{tabular}

Pathological stage 
Table 1 Correlations between FGF19 expression and clinicopathological parameters in 40 patients with HCC (Continued)

\begin{tabular}{cccc}
\hline II & 7 & $0.0004 \pm 0.0002$ & 0.049 \\
III & 14 & $0.020 \pm 0.016$ & \\
IV & 19 & $0.009 \pm 0.007$ & \\
\hline HBV hepatitis B virus, HCV hepatitis C virus, AFP alpha-fetoprotein, SE. standard error
\end{tabular}

HBV hepatitis B virus, $H C V$ hepatitis $C$ virus, AFP alpha-fetoprotein, S.E. standard error

overall survival rates to assess the prognostic significance of FGF19. The 5-year disease-free and overall survival rates of the 40 patients with $\mathrm{HCC}$ were $10 \%$ and $40 \%$, respectively. Using the Kaplan-Meier curve assessment, we found that patients with higher FGF19 expression levels had lower 5-year survival rates than patients with lower FGF19 expression levels (disease-free survival rate, $0 \%$ vs. $20 \% ; P=0.0061$; overall survival rate, $20 \%$ vs. $60 \% ; P=0.0046$; as shown in Figure 2). To evaluate the potential of using FGF19 expression in determining the postoperative prognosis of HCC patients, univariate analysis using a Cox proportional hazard regression model was conducted (Table 2). The results showed that the serum AFP index, FGF19 mRNA level, and intrahepatic metastasis were significant predictors of disease-free survival $(P=0.004,0.021$, and 0.020 , respectively), while Milan criteria, serum AFP index, FGF19 mRNA level, tumor size, and intrahepatic metastasis were significant predictors of overall survival $(P=0.006$, $0.042,0.018,0.028$ and 0.020 , respectively). Multivariate analysis was conducted with 5 prime variables that are regarded as prognostic factors for patients with $\mathrm{HCC}$ in previous studies because of the small sample size of patients (Table 3)[30]. A high FGF19 mRNA level remained significant in both disease-free survival and overall survival, and was the strongest in overall survival
$(P=0.040$ and 0.003 , odds ratio $=2.34$ and 3.61 , respectively).

\section{FGF19 expression of the HCC cell lines}

We used RT-PCR to analyze the differential expression of FGF19 by measuring mRNA levels among $10 \mathrm{HCC}$ lines. FGF19 mRNA was expressed in all HCC lines, and at a remarkably higher level in $\mathrm{JHH} 7$ (Figure 3A). FGF19 protein was detected using an FGF19 ELISA kit in culture media for all human HCC lines and normal hepatocyte at $72 \mathrm{~h}$ after seeding; FGF19 was noted to be significantly higher in JHH7 cells and significantly lower in normal hepatocyte (Figure 3B). An immunocytohistochemical study using anti-FGF19 monoclonal antibodies was performed to determine whether FGF19 is expressed in all HCC lines; FGF19 protein was detectable in all HCC lines in the cytoplasm (Figure 3C). Similarly, FGFR4 mRNA was expressed in all HCC lines (Figure 3D). Through FGFR4 staining, FGFR4 protein was observed in all HCC lines (Figure 3E).

\section{Proliferation, apoptosis assay, invasion, and migration} assay with FGF19 recombinant protein

We chose the HuH7, HepG2, HLE, HLF, and JHH7 cell lines upon consideration of the combination of FGF19 and FGFR4 levels. We cultured these HCC lines with
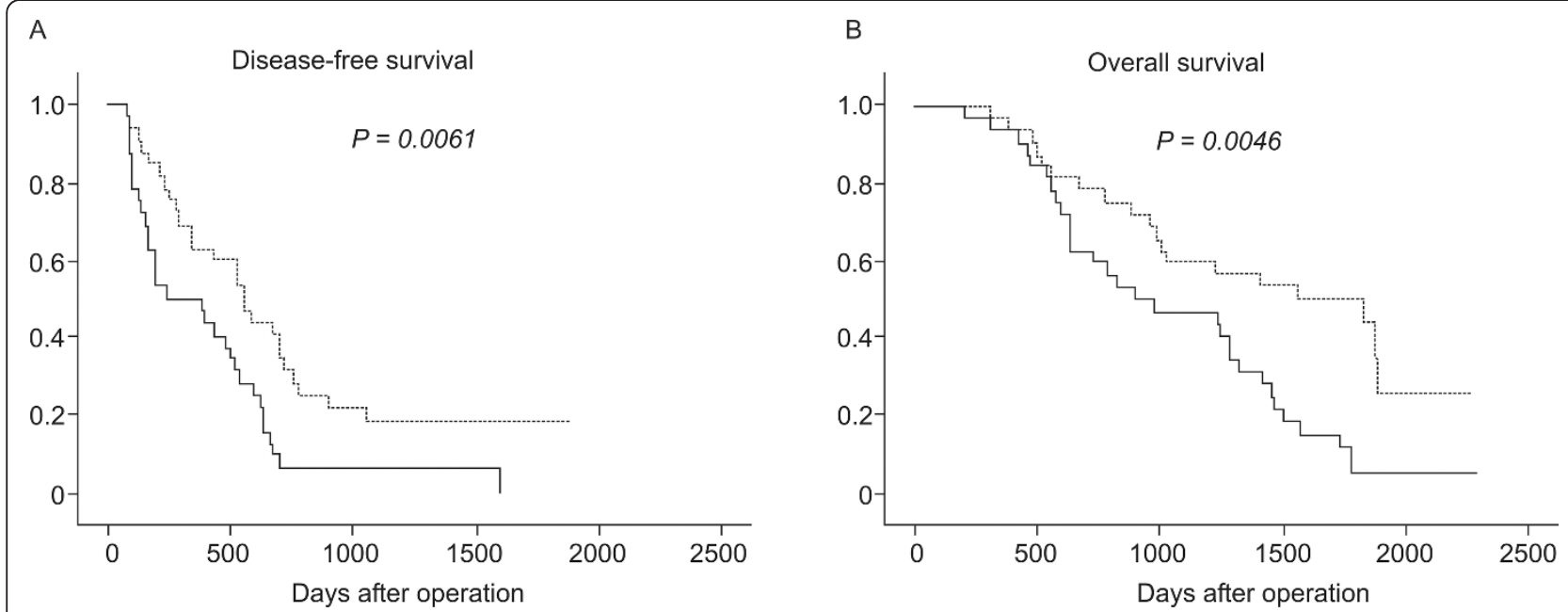

Figure $\mathbf{2}$ Survival rates of $\mathbf{4 0}$ patients with HCC. (A) Disease-free survival rates of patients with HCCs. (B) Overall survival rates of patients with HCCs. High expression of FGF19 mRNA was significantly associated with poorer prognosis. 
Table 2 Univariate analysis of disease-free and overall patient survivals with hepatocellular carcinoma

\begin{tabular}{|c|c|c|c|c|}
\hline Clinicopathological Parameters & Median Disease-free survival & $P$ value & Median Overall survival & $P$ value \\
\hline \multicolumn{5}{|l|}{ Age } \\
\hline$<65$ years & 237 & 0.349 & 1267 & 0.673 \\
\hline$\geq 65$ years & 594 & & 1234 & \\
\hline \multicolumn{5}{|l|}{ Gender } \\
\hline Male & 673 & 0.079 & 1283 & 0.568 \\
\hline Female & 283 & & 1092 & \\
\hline \multicolumn{5}{|l|}{ Virus } \\
\hline HBV & 237 & 0.178 & 1211 & 0.968 \\
\hline $\mathrm{HCV}$ & 325 & & 1283 & \\
\hline None & 847 & & 1234 & \\
\hline \multicolumn{5}{|l|}{ Miran Criteria } \\
\hline In & 847 & 0.061 & 1940 & 0.006 \\
\hline Out & 256 & & 572 & \\
\hline \multicolumn{5}{|l|}{ AFP } \\
\hline High $(n=20)$ & 237 & 0.004 & 573 & 0.042 \\
\hline \multicolumn{5}{|l|}{$>10 \mathrm{ng} / \mathrm{mL}$} \\
\hline Low $(n=20)$ & 847 & & 1818 & \\
\hline \multicolumn{5}{|l|}{$\leq 10 \mathrm{ng} / \mathrm{mL}$} \\
\hline \multicolumn{5}{|l|}{ FGF19T } \\
\hline High $(n=20)$ & 283 & 0.021 & 628 & 0.018 \\
\hline Low $(n=20)$ & 413 & & 1758 & \\
\hline \multicolumn{5}{|l|}{ Tumor size } \\
\hline$<5 \mathrm{~cm}$ & 717 & 0.171 & 1428 & 0.028 \\
\hline$\geq 5 \mathrm{~cm}$ & 256 & & 498 & \\
\hline \multicolumn{5}{|l|}{ Histologic type of tumor } \\
\hline Well differentiated & 673 & 0.813 & 1428 & 0.712 \\
\hline Moderately differentiated & 323 & & 1234 & \\
\hline Poorly differentiated & 594 & & 1092 & \\
\hline \multicolumn{5}{|l|}{ Formation of fibrous capsule } \\
\hline Present & 413 & -——- & 1267 & - - \\
\hline Absent & 64 & & 64 & \\
\hline \multicolumn{5}{|l|}{ Capsular infiltration } \\
\hline Present & 403 & 0.853 & 1234 & 0.725 \\
\hline Absent & 64 & & 64 & \\
\hline \multicolumn{5}{|l|}{ Septal formation } \\
\hline Present & 325 & 0.872 & 1230 & 0.777 \\
\hline Absent & 413 & & 1283 & \\
\hline \multicolumn{5}{|l|}{ Serosal invasion } \\
\hline Present & 104 & -二- & 172 & -二- \\
\hline Absent & 413 & & 1267 & \\
\hline \multicolumn{5}{|l|}{ Portal invasion } \\
\hline Present & 283 & & 825 & 0.105 \\
\hline Absent & 881 & & 1940 & \\
\hline \multicolumn{5}{|l|}{ Hepatic vein invasion } \\
\hline Present & 256 & 0.215 & 573 & 0.150 \\
\hline Absent & 597 & & 1428 & \\
\hline \multicolumn{5}{|l|}{ Intrahepatic metastasis } \\
\hline Present & 283 & 0.020 & 628 & 0.020 \\
\hline Absent & 881 & & 1983 & \\
\hline \multicolumn{5}{|l|}{ Bile duct invasion } \\
\hline Present & 403 & ———- & 1267 & -—— \\
\hline
\end{tabular}


Table 2 Univariate analysis of disease-free and overall patient survivals with hepatocellular carcinoma (Continued)

\begin{tabular}{|c|c|c|c|}
\hline Absent & 413 & 573 & \\
\hline \multicolumn{4}{|c|}{ Lymph node metastasis } \\
\hline Present & 256 & 347 & -— \\
\hline Absent & 413 & 1267 & \\
\hline \multicolumn{4}{|c|}{ Pathological stage } \\
\hline$\|$ & 1373 & 2085 & 0.060 \\
\hline III & 594 & 1234 & \\
\hline IV & 237 & 572 & \\
\hline
\end{tabular}

HBV hepatitis B virus, HCV hepatitis C virus, AFP alpha-fetoprotein

FGF19 recombinant protein at concentrations of 0.01 , $0.1,0.5,1,5,10,50$, or $100 \mathrm{ng} / \mathrm{mL}$ and performed a proliferation assay (Figure 4A; $n=12, P<0.05$ ). We found that the proliferation of all HCC cells examined increased significantly upon addition of FGF19 recombinant protein at concentrations of $0.01-10 \mathrm{ng} / \mathrm{mL}$ over 48-96 h (Figure 4B). The proliferation index was highest when the concentration of FGF19 was $1 \mathrm{ng} / \mathrm{mL}$ in the 5 HCC lines, whereas apoptosis of HCC cells was significantly suppressed by addition of $1 \mathrm{ng} / \mathrm{mL}$ FGF19 recombinant protein in culture media (Figure $5 \mathrm{~A} ; n=12, P<$ $0.05)$. Tumor metastasis is still a major problem in management of cancer. In order to investigate further whether FGF19 plays an important role in tumor metastasis, the invasion assay and migration assay were performed. Invasion assays were used to investigate the alteration of cancer cell invasiveness in the presence of FGF19 recombinant protein for JHH7. The assays were conducted by staining and measuring the OD at 560 $\mathrm{nm}$; they revealed that $1 \mathrm{ng} / \mathrm{mL}$ of the FGF19 recombinant protein significantly increased the mobility and invasiveness of the $\mathrm{JHH} 7$ cells (Figure $5 \mathrm{~B} ; n=6, P<$ $0.05)$. As shown in Figure $5 \mathrm{C}$, the number of migrated cells also increased dramatically after addition of the FGF19 recombinant protein (Figure $5 \mathrm{C} ; n=6, P<$
0.05). Results of the invasion assay and migration assay indicate that FGF19 may be an activator of tumor metastasis.

\section{Proliferation and apoptosis assay after FGF19 and FGFR4 siRNA}

We selected the JHH7 cell line for further studies because this HCC line showed the highest FGF19 expression at both the mRNA and protein levels in the 10 HCC lines examined. Transfection of FGF19 siRNA decreased FGF19 mRNA expression by $72 \%$ after $48 \mathrm{~h}$ as compared with cells transfected with control siRNA (Figure 6A). Maximum downregulation of FGF19 protein occurred at $72 \mathrm{~h}$ after transfection. The FGF19 protein was downregulated by more than $90 \%$ in the $\mathrm{JHH} 7$ cells (Figure 6B). Similarly, FGFR4 siRNA transfection downregulated mRNA (Figure 6C) and protein expression of FGFR4 (Figure 6D). Further, proliferation of JHH7 cells was significantly suppressed by FGF19 siRNA transfection (Figure $6 \mathrm{E} ; n=12, P<0.05$ ) and FGFR4 siRNA transfection $(n=12, P<0.05)$. We also found that apoptosis induced by 5 -FU increased significantly in the FGF19 siRNA group at $96 \mathrm{~h}$ after transfection (Figure 6F; $n=12, P<0.05$ ) and FGFR4 siRNA transfection $(n=12, P<0.05)$.

Table 3 Multivariate analysis of disease-free and overall patient survivals with hepatocellular carcinoma

\begin{tabular}{|c|c|c|c|c|c|c|}
\hline \multirow[t]{2}{*}{ Variable } & \multicolumn{3}{|c|}{ Disease-free survival } & \multicolumn{3}{|c|}{ Overall survival } \\
\hline & Hazard Ratio & 95\% C.I. & $P$ value & Hazard Ratio & 95\% C.I. & $P$ value \\
\hline Portal invasion (0-4) & 2.59 & $1.27-5.28$ & 0.009 & 2.74 & $1.31-5.73$ & 0.007 \\
\hline $\begin{array}{l}\text { AFP } \\
(\leq 10 \mathrm{ng} / \mathrm{mL}:>10 \mathrm{ng} / \mathrm{r}\end{array}$ & 2.49 & $1.09-5.72$ & 0.031 & 2.03 & $0.84-4.91$ & 0.114 \\
\hline $\begin{array}{l}\text { Tumor size } \\
(\leq 5 \mathrm{~cm}:>5 \mathrm{~cm})\end{array}$ & 0.58 & $0.14-2.35$ & 0.445 & 0.87 & $0.21-3.56$ & 0.845 \\
\hline $\begin{array}{l}\text { Intrahepatic metastasis } \\
\text { (absent: present) }\end{array}$ & 1.25 & $0.60-2.60$ & 0.550 & 1.53 & $0.66-3.53$ & 0.319 \\
\hline $\begin{array}{l}\text { Miran criteria } \\
\text { (in: out) }\end{array}$ & 0.31 & $0.76-1.27$ & 0.105 & 0.28 & $0.07-1.19$ & 0.085 \\
\hline $\begin{array}{l}\text { tumor FGF19 } \\
\text { (high: low) }\end{array}$ & 2.34 & $1.04-5.26$ & 0.040 & 3.61 & $1.56-8.36$ & 0.003 \\
\hline
\end{tabular}

AFP alpha-fetoprotein, C.I. confidence interval 
B

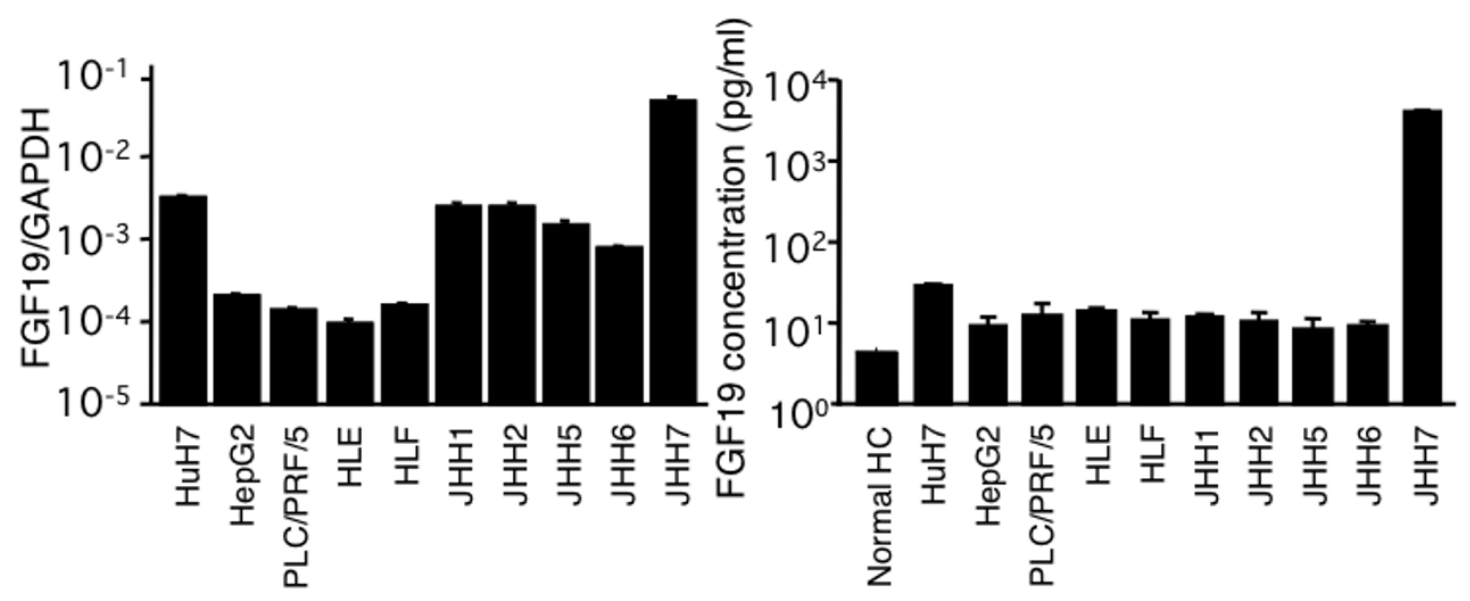

C

$\mathrm{HuH} 7$

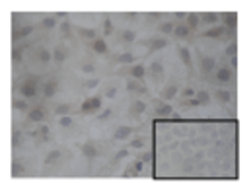

HLF

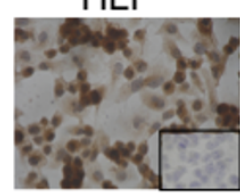

HepG2

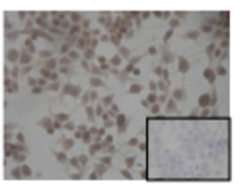

$\mathrm{JHH} 7$

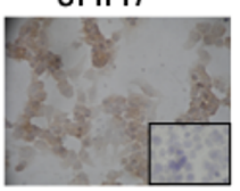

HLE

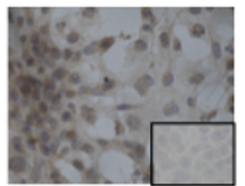

$\times 400$

E

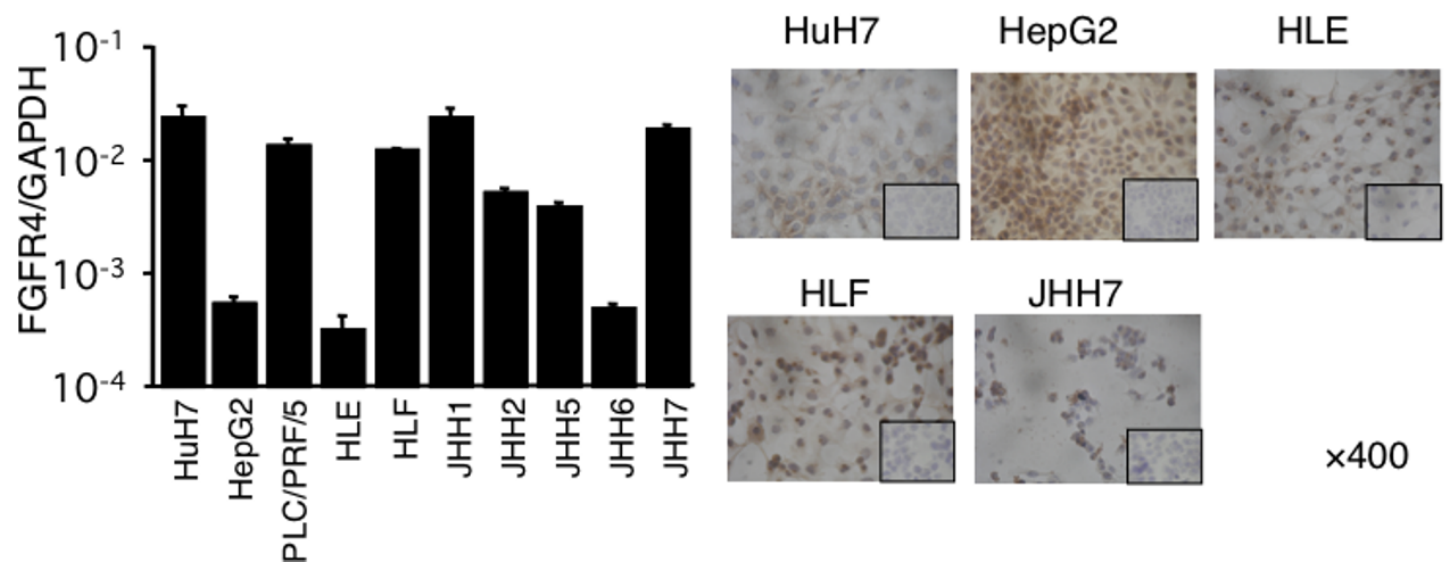

Figure 3 (A) FGF19 mRNA expression in cell extracts from HuH7, HepG2, PLC/PRF/5, HLE, HLF, JHH1, JHH2, JHH5, JHH6, and JHH7 cell lines was examined using quantitative RT-PCR $(\boldsymbol{n}=\mathbf{8})$. FGF19 was expressed in all cell lines. (B) FGF19 protein levels in the supernatant

media from ten cell lines and normal hepatocytes (normal HC) were assayed by ELISA. FGF19 was detected in the supernatant of all of them. (C) Using anti-FGF19 monoclonal antibodies, diffuse positive staining was demonstrated in the cytoplasm of HuH7, HepG2, HLE, HLF, and JHH7 cells. The closed rectangles indicate the same cells stained Immunohistochemically using control antibody. (D) FGFR4 mRNA expression in cell extracts from HuH7, HepG2, PLC/PRF/5, HLE, HLF, JHH1, JHH2, JHH5, JHH6, and JHH7 cell lines was examined using quantitative RT-PCR $(n=8)$. FGFR4 was expressed in all cell lines. (E) Using anti-FGFR4 monoclonal antibodies, positive staining was demonstrated in the cell membranes of all of the above HCC lines. (Original magnifications $(\mathbf{C}) \times 400),(\mathbf{E}) \times 400)$ ) The closed rectangles indicate the same cells stained Immunohistochemically using control antibody. 

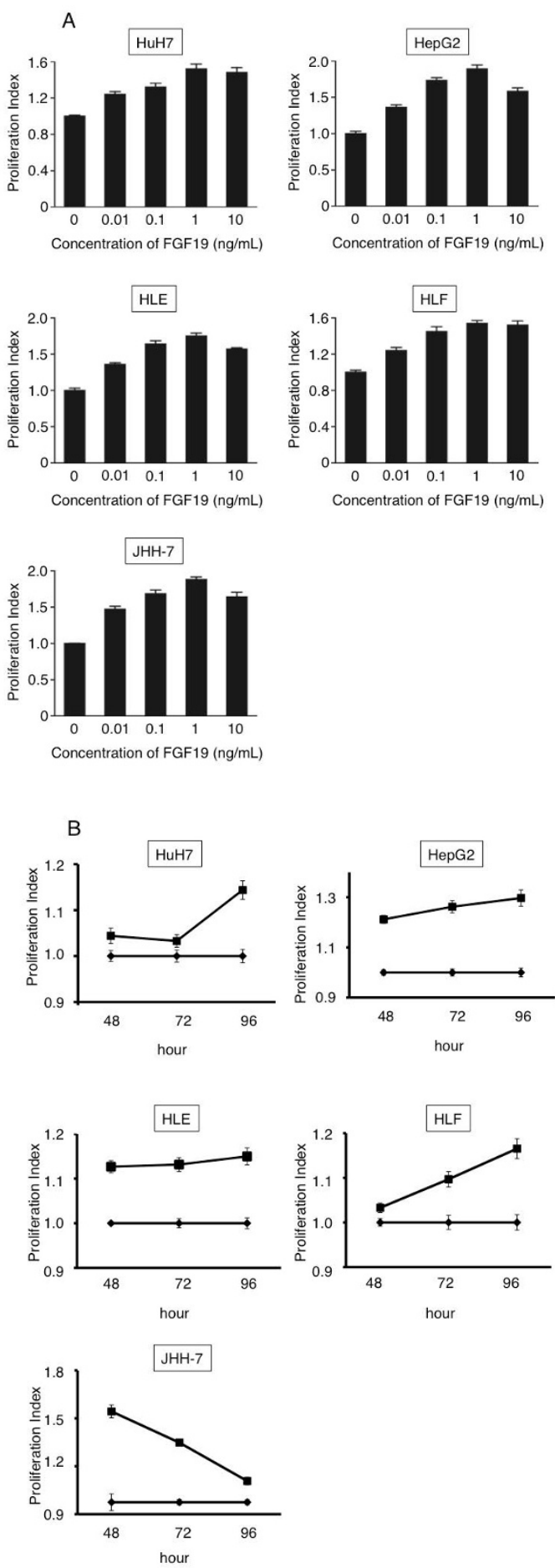

Figure 4 (A) Proliferation changes after addition of various concentration of the FGF19 recombinant protein. (B) The

proliferation index (PI) was defined as the OD values of cells treated with recombinant protein divided by those of untreated cells. The PI increased after addition of FGF19 recombinant protein (0.01-10 $\mathrm{ng} / \mathrm{mL}$ final concentration) to culture media and culturing for $96 \mathrm{~h}$. $\mathrm{PI}$, proliferation index.
A

A

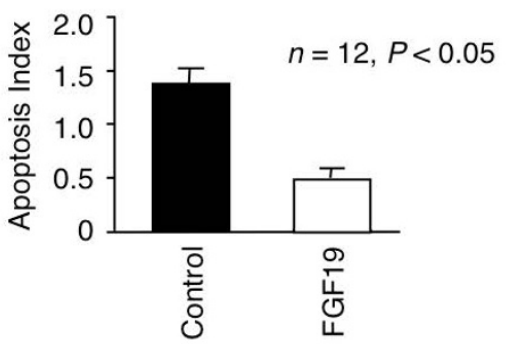

B
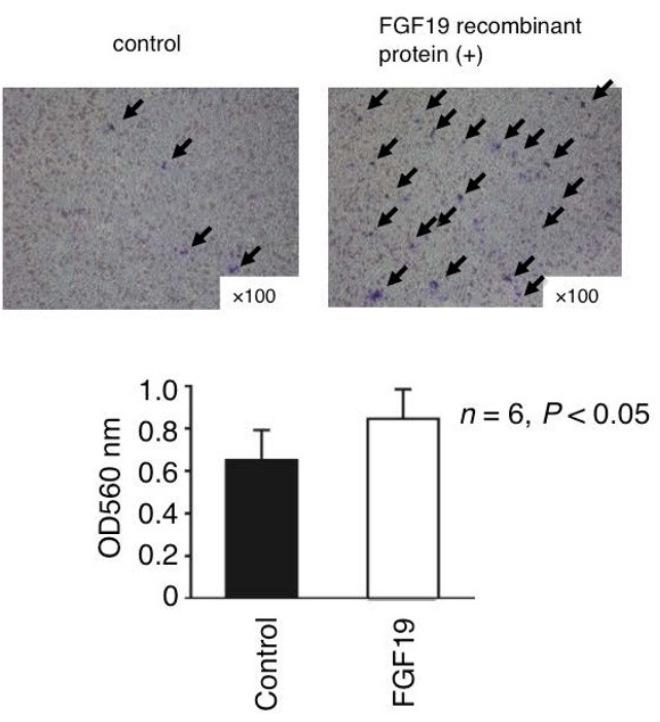

C

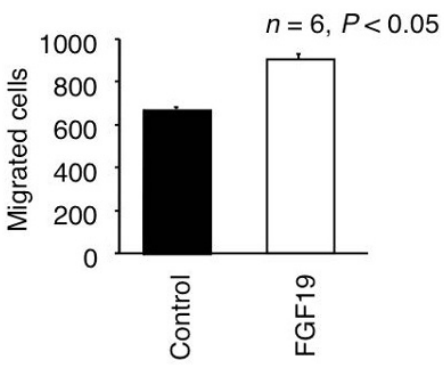

Figure 5 (A) Apoptosis assay at $72 \mathrm{~h}$ after FGF19 recombinant protein treatment. (left) 5-FU treatment; (right) 5-FU and recombinant protein treatment. The apoptosis index (Al) was defined as the $O D$ values of cells treated with these agents divided by those of untreated cells. (B) (upper) Invasion assay after FGF19 recombinant protein treatment (100× magnification). (lower) Invasion assay $48 \mathrm{~h}$ after FGF19 recombinant protein treatment after FGF19 recombinant protein treatment. (C) FGF19 enhanced cell migration ability in $\mathrm{JHH7}$ cell line. The transwell system was used to evaluate migratory ability. Migrated cells were counted and the quantitative results are shown $(n=6)$. The data presented are from a representative experiment, being quantitatively similar in the replicate experiments. 

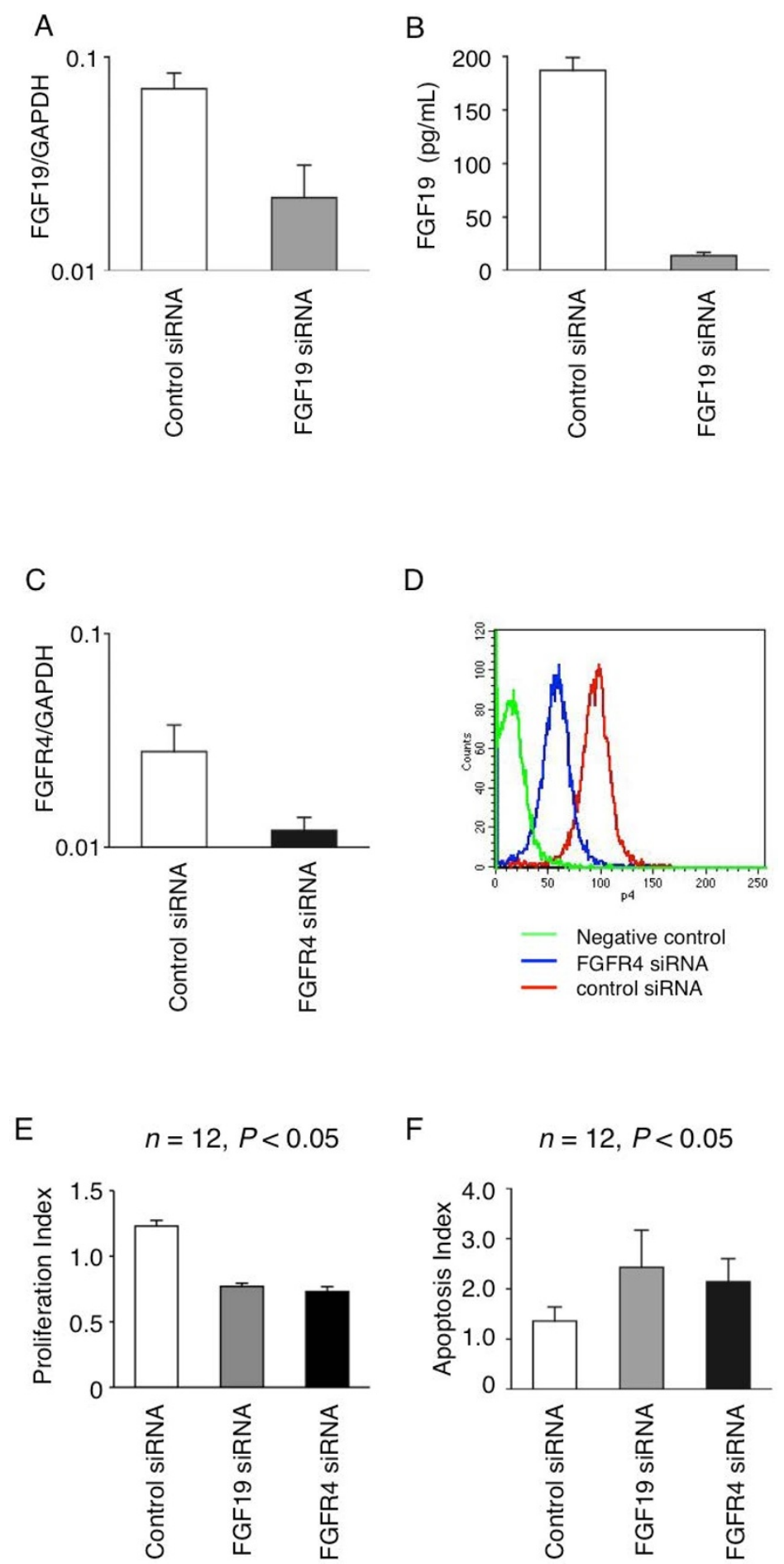

$\mathrm{F}$

$$
n=12, P<0.05
$$

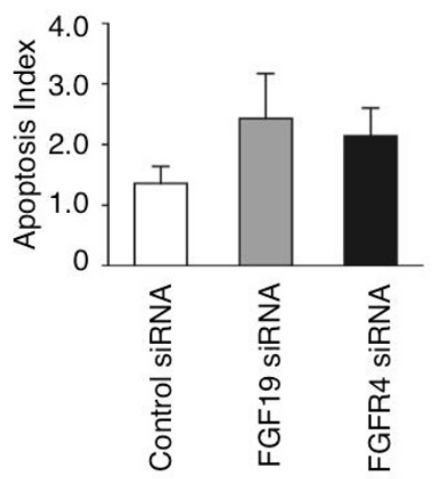

Figure 6 Suppression of FGF19 expression was confirmed at transcript level by RT-PCR. (A) and at protein level by ELISA analysis (B) Analysis was performed at $48 \mathrm{~h}$ and $72 \mathrm{~h}$ following siRNA transfection for mRNA and protein level, respectively. FGF19 mRNA expression was suppressed to $30 \%$ of control siRNA in FGF19-specific siRNA-treated cells. $n=12, \mathrm{P}<0.05$ at top of the Figure 6A, 6B, and 6C (like figure 6E and 6D). FGFR4 gene silencing by siRNA. Suppression of FGFR4 expression was confirmed at transcript level by RT-PCR (C) and at protein level by flow cytometry (D). Analysis was performed at $48 \mathrm{~h}$ and $72 \mathrm{~h}$ following siRNA transfection for mRNA and protein levels, respectively. FGFR4 mRNA expression was suppressed to $40 \%$ of control siRNA in FGFR4-specific siRNA-treated cells. $\mathrm{n}=12, \mathrm{P}<0.05$ at top of the Figure $6 \mathrm{~A}$, $6 \mathrm{~B}$, and 6C (like figure 6E and 6D). (E) Proliferation assay in JHH7 cells at $72 \mathrm{~h}$ after FGF19/FGFR4 siRNA treatment. (F) Apoptosis assay in JHH7 cells at 96 h after FGF19/FGFR4 siRNA treatment. Pl, Proliferation Index. Al, Apoptosis Index. 


\section{Changes in serum FGF19 level in patients with HCC after hepatectomy}

Serum FGF19 levels were measured at the pre- and postoperative period. Serum FGF19 levels of 10 normal subject were also measured. Postoperative FGF19 levels were significantly lower than those in the preoperative period (Figure 7; $n=29, P<0.05$ ). Moreover, FGF19 levels in the normal subjects were significantly lower than those in the preoperative period and significantly higher than those in the postoperative period (Figure 7 , $P<0.05)$.

\section{Discussion}

In this study, we clarified the association between the FGF19/FGFR4 system and the development of HCC using human samples and in vitro experimental models. FGF19 was expressed at significantly higher levels in HCCs, whereas the receptor FGFR4 was expressed in noncancerous tissue and HCC at similar levels. Han Kiat Ho et al., reported that one third of $\mathrm{HCC}$ patients exhibited increased FGFR4 mRNA expression in the matched tumor/normal tissue [29]. In our study, FGFR4 mRNA expression showed no significant difference but increased tendency (Figure $1 \mathrm{~B}, P=0.055$ ) in cancer tissue compared with adjacent tissue. Therefore we believe that there is no confliction between the both reports. Further, serum FGF19 significantly decreased after curative hepatectomy. Therefore, FGF19 appears to function in an autocrine or paracrine fashion. FGF19 mRNA expression was correlated with prognostic significance for the survival of patients with HCC. Thus, this is the first report showing the clinical importance of FGF19. These in vitro studies revealed that recombinant FGF19 could induce proliferation, stimulate invasion, and inhibit apoptosis in HCC lines. Inversely, the introduction of FGF19 and FGFR4 siRNA was able to reduce proliferation and increase apoptosis in HCC lines. These findings suggest that the FGF19/FGFR4 system plays a critical role in $\mathrm{HCC}$ progression.

The mRNA expression levels of FGF19 and FGFR4 in HCC have been shown as $46 \%$ and $60 \%$, respectively, by in situ hybridization [28]. In our study, all the examined human samples expressed both FGF19 and FGFR4 mRNA and the corresponding proteins. Further, all the cell lines examined expressed both FGF19 and FGFR4 at the higher level than normal hepatocyte. These results suggest that FGF19/FGFR4 are generally expressed in HCC. We investigated the correlation between FGF19 expression and the clinicopathological parameters in HCC. Our data indicated significant correlation in our cohort between FGF19 expression and pathological stage. The reason why FGF19 had no significant correlation with other prognostic factors, such as tumor size and vessel invasion, may be the small number of samples included in this study. Univariate and multivariate analyses revealed FGF19 to be an independent prognostic factor in $\mathrm{HCC}$ patients. These results indicate that high levels of FGF19 might help to identify HCC patients with poor prognoses and that FGF19 could be a novel prognostic marker of HCC. However, the detailed mechanism by which high levels of FGF19 contributes to the poor prognosis of patients with HCC must be elucidated by further study. However, we consider that FGF19 is certainly involved in the progression of HCC because recombinant protein and siRNA transfection were capable of affecting proliferation, invasion, and apoptosis in the experimental models.

Previous multivariate analyses have identified several variables as independent predictors of patient prognosis (tumor size, number of lesions, portal vein invasion, etc.) in patients who were not treated surgically and in those who underwent surgical resection. Further, a number of molecular markers with prognostic significance have been identified in HCC [32]. In this study, we showed that FGF19 is a novel independent prognostic factor for both disease-free and overall survival (Table 3). Moreover, serum FGF19 levels significantly decreased in HCC patients after curative operations (Figure 7). The sensitivity of serum FGF19 renders it a promising tumor marker for HCC. These results strongly indicate that FGF19 in surgically excised HCC tissues or preoperatively in the blood serum might help to identify patients with aggressive disease who will need adjuvant therapy.

In this study, we examined whether the introduction of siRNA into HCC cell lines could suppress the proliferative and anti-apoptotic properties of the HCC cell lines in vitro. FGF19 siRNA successfully suppressed FGF19 mRNA and FGF19 protein expression in the high FGF19-expressing cell line JHH7. Further, the proliferative and anti-apoptotic properties of JHH7 were lost in vitro after FGF19 siRNA transfection. Transfection of FGFR4 siRNA showed similar results. Recently, Desnoyers et al. have reported that neutralizing antibody of FGF19 treatment significantly suppressed the growth of established colon cancer tumors in vivo [28]. RNAi has been effectively used in target-directed therapies in a range of diseases and in the silencing of tumor genes by systemically administered siRNA in vivo [33-35]. Likewise, with antibody treatment, FGF19 and FGFR4 siRNA also may be potential targets for systemic therapy for HCC.

\section{Conclusions}

In conclusion, our results demonstrated that FGF19 expression was significantly upregulated in HCCs, with higher expression being correlated with poor prognosis. Our results raise the possibility for potential treatment 


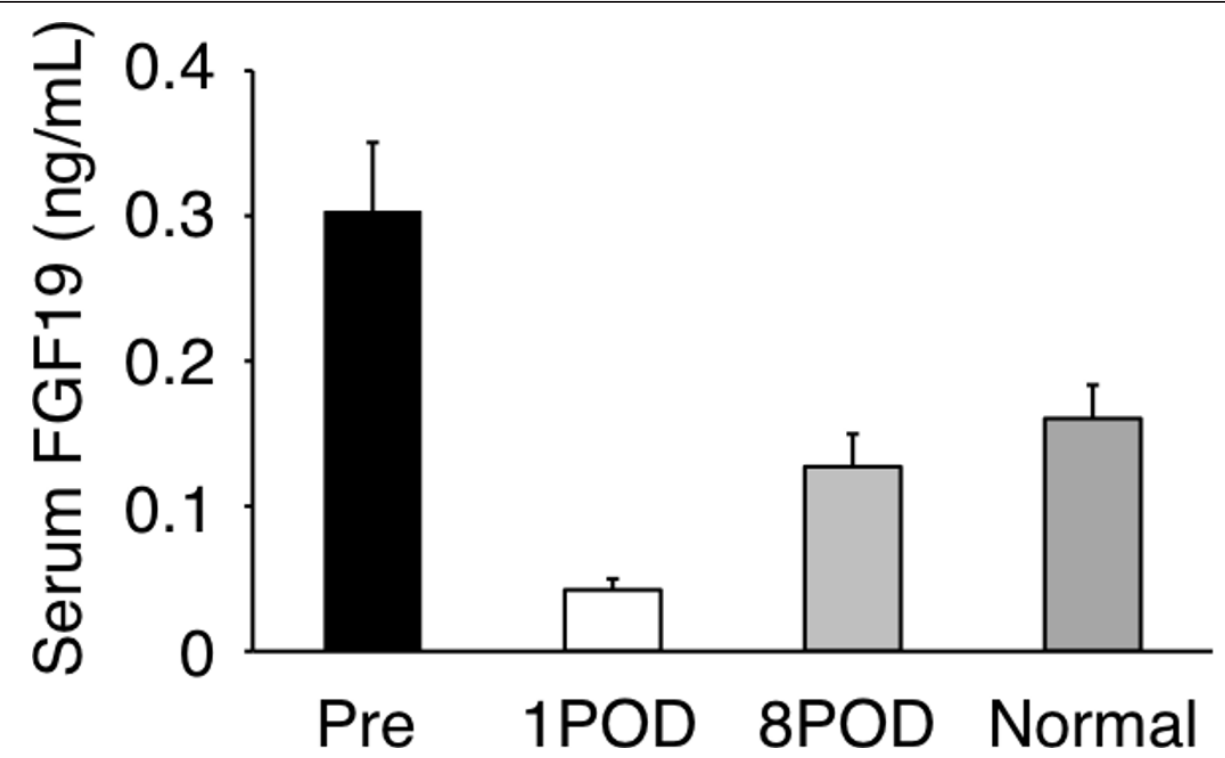

Figure 7 The changes in serum FGF19 levels, as measured by ELISA, of the 29 patients with HCCs from $1^{\text {st }}$ day and the $8^{\text {th }}$ day after curative resection surgery. Normal shows serum FGF19 levels of the 10 health subjects.

strategies aimed at functional abrogation of FGF19 that provide new therapeutic approaches in the management of HCC.

\section{Abbreviations \\ siRNA: Small interfering RNA; FGF: Fibroblast growth factor; HCC: \\ Hepatocellular carcinoma; 5-FU: 5-fluorouracil; RT-PCR: Reverse-transcription polymerase chain reaction.}

\section{Authors' contributions}

SM participated in the study design, carried out the in vivo experiments and evaluation of immunohistochemical staining, and drafted the manuscript. NM participated in the study design and helped to draft the manuscript. HS and FK coordinated and performed the statistical analysis and helped to draft the manuscript. $\mathrm{HY}$ and $\mathrm{MO}$ participated in the study design. AK, TS, and DO carried out in vitro experiments and performed statistical analysis. MM participated in the study design, carried out evaluation and validation of immunohistochemical staining, and helped to draft the manuscript. All authors have read and approved the final manuscript.

\section{Competing interests}

The authors declare that they have no competing interests.

Received: 23 September 2011 Accepted: 6 February 2012 Published: 6 February 2012

\section{References}

1. Parkin DM: Global cancer statistics in the year 2000. Lancet Oncol 2001, 2:533-543

2. Carr BI: Hepatocellular carcinoma: current management and future trends. Gastroenterology 2004, 127:S218-S224.

3. Bruix J, Sherman M: Management of hepatocellular carcinoma. Hepatology 2005, 42:1208-1236.

4. El-Serag HB, Rudolph KL: Hepatocellular carcinoma: epidemiology and molecular carcinogenesis. Gastroenterology 2007, 132:2557-2576.

5. Chen YJ, Yeh SH, Chen JT, et al: Chromosomal changes and clonality relationship between primary and recurrent hepatocellular carcinoma. Gastroenterology 2000, 119:431-440.
6. Imamura H, Matsuyama $\mathrm{Y}$, Tanaka $\mathrm{E}$, et al: Risk factors contributing to early and late phase intrahepatic recurrence of hepatocellular carcinoma after hepatectomy. J Hepatol 2003, 38:200-207.

7. Itoh N, Ornitz DM: Evolution of the Fgf and Fgfr gene families. Trends Genet 2004, 20:563-569.

8. Eswarakumar VP, Lax I, Schlessinger J: Cellular signaling by fibroblast growth factor receptors. Cytokine Growth Factor Rev 2005, 16:139-149.

9. Schlessinger J: Common and distinct elements in cellular signaling via EGF and FGF receptors. Science 2004, 306:1506-1507.

10. Richelda R, Ronchetti $D$, Baldini $L$, et al: A novel chromosomal translocation $\mathrm{t}(4,14)(\mathrm{p} 16.3, \mathrm{q} 32)$ in multiple myeloma involves the fibroblast growth-factor receptor 3 gene. Blood 1997, 90:4062-4070.

11. Zaharieva BM, Simon R, Diener PA, et al: High-throughput tissue microarray analysis of 11 q13 gene amplification (CCND1, FGF3, FGF4, EMS1) in urinary bladder cancer. J Pathol 2003, 201:603-608.

12. Xiao $S$, Nalabolu SR, Aster JC, et al: FGFR1 is fused with a novel zinc-finger gene, ZNF198, in the $t(8,13)$ leukaemia/lymphoma syndrome. Nat Genet $1998,18: 84-87$

13. Shimokawa T, Furukawa Y, Sakai M, et al: Involvement of the FGF18 gene in colorectal carcinogenesis, as a novel downstream target of the betacatenin/T-cell factor complex. Cancer Res 2003, 63:6116-6120.

14. Ruohola JK, Viitanen TP, Valve EM, et al: Enhanced invasion and tumor growth of fibroblast growth factor 8b-overexpressing MCF-7 human breast cancer cells. Cancer Res 2001, 61:4229-4237.

15. Gowardhan B, Douglas DA, Mathers ME, et al: Evaluation of the fibroblast growth factor system as a potential target for therapy in human prostate cancer. Br J Cancer 2005, 92:320-327.

16. McLeskey SW, Ding IY, Lippman ME, et al: MDA-MB-134 breast carcinoma cells overexpress fibroblast growth factor (FGF) receptors and are growth-inhibited by FGF ligands. Cancer Res 1994, 54:523-530.

17. Streit S, Bange J, Fichtner A, et al: Involvement of the FGFR4 Arg388 allele in head and neck squamous cell carcinoma. Int I Cancer 2004, 111:213-217.

18. Qian ZR, Sano T, Asa SL, et al: Cytoplasmic expression of fibroblast growth factor receptor-4 in human pituitary adenomas: relation to tumor type, size, proliferation, and invasiveness. J Clin Endocrinol Metab 2004, 89:1904-1911.

19. Bange J, Prechtl D, Cheburkin Y, et al: Cancer progression and tumor cell motility are associated with the FGFR4 Arg(388) allele. Cancer Res 2002, 62:840-847. 
20. Wang J, Stockton DW, Ittmann M: The fibroblast growth factor receptor-4 Arg388 allele is associated with prostate cancer initiation and progression. Clin Cancer Res 2004, 10:6169-6178.

21. Spinola M, Leoni V, Pignatiello C, et al: Functional FGFR4 Gly388Arg polymorphism predicts prognosis in lung adenocarcinoma patients. $J$ Clin Oncol 2005, 23:7307-7311.

22. Ornitz DM, Itoh N: Fibroblast growth factors. Genome Biol 2001, 2: REVIEWS3005

23. Harmer NJ, Pellegrini L, Chirgadze D, et al: The crystal structure of fibroblast growth factor (FGF) 19 reveals novel features of the FGF family and offers a structural basis for its unusual receptor affinity. Biochemistry 2004, 43:629-640.

24. Ornitz DM, Xu J, Colvin JS, et al: Receptor specificity of the fibroblast growth factor family. J Biol Chem 1996, 271:15292-15297.

25. Holt JA, Luo G, Billin AN, et al: Definition of a novel growth factordependent signal cascade for the suppression of bile acid biosynthesis. Genes Dev 2003, 17:1581-1591.

26. Fu L, John LM, Adams SH, et al: Fibroblast growth factor 19 increases metabolic rate and reverses dietary and leptin-deficient diabetes. Endocrinology 2004, 145:2594-2603.

27. Nicholes K, Guillet S, Tomlinson E, et al: Mouse model of hepatocellular carcinoma: ectopic expression of fibroblast growth factor 19 in skeletal muscle of transgenic mice. Am J Pathol 2002, 160:2295-2307.

28. Desnoyers LR, Pai R, Ferrando RE, et al: Targeting FGF19 inhibits tumor growth in colon cancer xenograft and FGF19 transgenic hepatocellular carcinoma models. Oncogene 2008, 27:85-97.

29. Ho HK, Pok S, Streit S, et al: Fibroblast growth factor receptor 4 regulates proliferation, anti-apoptosis and alpha-fetoprotein secretion during hepatocellular carcinoma progression and represents a potential target for therapeutic intervention. J Hepatol 2009, 50:118-127.

30. Arii S, Okamoto E, Imamura M: Registries in Japan: current status of hepatocellular carcinoma in Japan. Liver Cancer Study Group of Japan. Semin Surg Oncol 1996, 12:204-211.

31. Diaz D, Fabre I, Daujat $M$, et al: Omeprazole is an aryl hydrocarbon-like inducer of human hepatic cytochrome P450. Gastroenterology 1990, 99:737-747.

32. Mitsuhashi N, Shimizu H, Ohtsuka M, et al: Angiopoietins and Tie-2 expression in angiogenesis and proliferation of human hepatocellular carcinoma. Hepatology 2003, 37:1105-1113.

33. Li K, Lin SY, Brunicardi FC, et al: Use of RNA interference to target cyclin E-overexpressing hepatocellular carcinoma. Cancer Res 2003, 63:3593-3597.

34. Duxbury MS, Matros $\mathrm{E}$, Ito $\mathrm{H}$, et al: Systemic siRNA-mediated gene silencing: a new approach to targeted therapy of cancer. Ann Surg 2004, 240:667-674, discussion 675-666.

35. Cho-Rok J, Yoo J, Jang YJ, et al: Adenovirus-mediated transfer of siRNA against PTTG1 inhibits liver cancer cell growth in vitro and in vivo. Hepatology 2006, 43:1042-1052.

\section{Pre-publication history}

The pre-publication history for this paper can be accessed here: http://www.biomedcentral.com/1471-2407/12/56/prepub

doi:10.1186/1471-2407-12-56

Cite this article as: Miura et al.: Fibroblast growth factor 19 expression correlates with tumor progression and poorer prognosis of hepatocellular carcinoma. BMC Cancer 2012 12.56.

\section{Submit your next manuscript to BioMed Central and take full advantage of:}

- Convenient online submission

- Thorough peer review

- No space constraints or color figure charges

- Immediate publication on acceptance

- Inclusion in PubMed, CAS, Scopus and Google Scholar

- Research which is freely available for redistribution

Submit your manuscript at www.biomedcentral.com/submit
C) Biomed Central 